\title{
Detection of anti-Borrelia burgdorferi antibodies in buffaloes (Bubalus bubalis) in the state of Pará, Brazil
}

\author{
Detecção de anticorpos anti-Borrelia burgdorferi em búfalos (Bubalus bubalis) no estado do Pará, Brasil \\ Fabíola do Nascimento Corrêa ${ }^{1}$; Rafaella Câmara Teixeira ${ }^{1}$; Carlos Magno Chaves Oliveira²; José Diomedes Barbosa²; \\ Adivaldo Henrique da Fonseca ${ }^{1 *}$
} ${ }^{1}$ Curso de Pós-graduação em Ciências Veterinárias, Instituto de Veterinária, Universidade Federal Rural do Rio de Janeiro - UFRRJ,
Seropédica, RJ, Brasil

${ }^{2}$ Faculdade de Medicina Veterinária, Universidade Federal do Pará - UFPA, Castanhal, PA, Brasil

Received December 8, 2011

Accepted May 16, 2012

\begin{abstract}
This study aimed to investigate the frequency of homologous antibodies of IgG class against Borrelia burgdorferi in buffaloes in the state of Pará, Brazil. Blood serum samples from 491 buffaloes were analyzed by means of the indirect ELISA test, using crude antigen produced from a cultivar of the North American strain G39/40 of B. burgdorferi. There were 412 positive samples (83.91\%), and there was no statistically significant difference in the proportions of positive animals between the $81.69 \%$ (232/284) originating from Marajó Island and the $86.96 \%$ (180/207) from the continental area of the state of Pará. In all the municipalities studied, the frequency of positive findings of antibodies against $B$. burgdorferi among the animals ranged from $63.6 \%$ to $92.9 \%$. The high numbers of seropositive animals can be explained by the frequent presence of the tick Rhipicephalus (Boophilus) microplus, and by the possible existence of spirochetes of the genus Borrelia infecting buffaloes in the region studied, although specific studies are needed to confirm this relationship. These factors suggest that a cross-reaction exists between the North American strain G39/40 of B. burgdorferi, which is used as an antigenic substrate, and the species of Borrelia spp. that possibly infects buffaloes in the state of Pará.
\end{abstract}

Keywords: Buffaloes, Borrelia spp., epidemiology, serology.

\section{Resumo}

Este estudo teve como objetivo investigar a frequência de anticorpos homólogos da classe IgG contra Borrelia burgdorferi em búfalos do estado do Pará. Amostras de soro de 491 búfalos foram analisadas por meio do teste ELISA indireto, utilizando antígeno bruto produzido a partir do cultivo da cepa norte americana G39/40 de B. burgdorferi. Foram encontrados 412 soros positivos (83,91\%), não havendo diferença estatística significativa entre os 81,69\% (232/284) animais positivos provenientes da Ilha de Marajó e os 86,96\% (180/207) da base continental do estado do Pará. Em todos os municípios estudados os animais apresentaram frequência de anticorpos contra $B$. burgdorferi, com positividade variando de $63,6 \%$ a $92,9 \%$. O alto número de soropositivos pode ser explicado pela frequente presença do carrapato Rhipicephalus (Boophilus) microplus e pela possível existência de espiroquetas do gênero Borrelia infectando búfalo na região estudada, embora novos estudos sejam necessários para a confirmação desta relação. Estes fatos sugerem reaçáo cruzada entre a cepa americana G39/40 de B. burgdorferi utilizada como substrato antigênico e a espécie de Borrelia spp. que possivelmente infecta bubalinos no estado do Pará.

Palavras-chave: Búfalos, Borrelia spp., epidemiologia, sorologia.

\section{Introduction}

Borreliosis is a systemic anthropozoonosis, an infectious spirochetal disease of the group Borrelia burgdorferi sensu lato that is found in North America and Europe (RUDENKO et al., 2009).

*Corresponding author: Adivaldo Henrique da Fonseca

Departamento Epidemiologia e Saúde Pública, Instituto de Veterinária,

Universidade Federal Rural do Rio de Janeiro - UFRRJ, BR 465, Km 07,

Bairro Ecologia, CEP 23890-000, Seropédica, RJ, Brasil

e-mail: adivaldo@ufrrj.br
Similarly to what is observed in humans, these microorganisms can infect species of domestic animals and wildlife, and they are transmitted primarily by ticks (LITTLE et al., 2010). Various tick species have been described as parasitizing buffaloes (NITHIKATHKUL et al., 2002), which makes them possible hosts for the etiological agents transmitted by these arthropods.

Buffalo production in Brazil is an activity that has been attracting the attention of the scientific community with regard to aspects 
of buffalo health. Buffaloes have anatomical and physiological characteristics that confer on them great rusticity, which facilitates development of the subclinical state of many infections (LÁU, 1999). The theory that buffaloes are highly resistant to diseases has led to their health being treated with little attention, without taking into consideration the possibility that buffaloes may participate in maintaining the epidemiological cycle of etiological agents of diseases of importance to livestock and public health.

The first observation of Borrelia spp. in buffaloes was made in a native buffalo in the municipality of Castanhal, state of Pará. Guedes Junior et al. (2008) found 54.9\% (135/246) cattle positives to homologues antibodies to B. burgdorferi. (GALO et al., 2009), found $26,7 \%$ (80/300) horses positives to homologues antibodies to $B$. burgdorferi, both in the same region. On the basis of this finding, the current study aimed to evaluate the frequency of homologous anti- $B$. burgdorferi antibodies, using the indirect enzymatic immunoabsorption (ELISA) test, on blood serum samples from buffaloes in the state of Pará, Brazil.

\section{Materials and Methods}

For this study, blood samples were collected from 491 young and adult buffaloes of the Murrah breed that were apparently healthy. Animal recruitment was carried out by non-probabilistic sampling. Among these animals, 284 came from the municipality of Cachoeira do Arari, Marajó Island. A further 207 animals came from four municipalities situated in the continental part of Pará: 66 animals from Castanhal, 22 from Santa Isabel, 63 from Santarém Novo and 56 from Nova Timboteua. The animals' blood was obtained in an aseptic form by means of jugular venal puncture and was decanted into sterile tubes without anticoagulant. The serum was sampled into microtubes and stored at $-20{ }^{\circ} \mathrm{C}$ until it was serologically analyzed.

The antigen used for serological tests came from a cultivar of the G39/40 strain of B. burgdorferi stricto sensu, of North American origin. Spirochetes were put to grow in Barbour-Stoenner-Kelly (BSK-H) medium and, at maximal bacterial increase, antigens were produced as described by Ishikawa et al. (1997). The B. burgdorferi G39/40 strain was kindly provided by Professor Dr. Natalino Hajime Yoshinari, of the Medical Investigation Laboratory for Rheumatology, Hospital das Clínicas, School of Medicine of the University of São Paulo (LIM-17/HCFMUSP).

Prior to the serological analyses, validation of the indirect ELISA test standardized by Ishikawa et al. (1997) was performed. In a high adsorption ELISA plate (Costar 3590, Corning ), tests were carried out with various antigen concentrations $(10 \mu \mathrm{g} / \mathrm{mL}$, $15 \mu \mathrm{g} / \mathrm{mL}$ and $20 \mu \mathrm{g} / \mathrm{mL}$ ); two serum dilutions (1:400 and 1:800), of which two were positive and two were negative in duplicate; and two dilutions of rabbit anti-bovine IgG conjugated to alkaline phosphatase (Sigma Chemical') (1:5000 and 1:10000). The results obtained by means of spectrophotometry were expressed as optical density values (OD). The best combination for producing the greatest difference between the positive and the negative serum samples was chosen. The ELISA assay on buffalo serum samples was done using the technique described by Ishikawa et al. (1997), with modifications.
The cutoff for each ELISA plate was calculated according to the mathematical formula of Frey et al. (1998), which is based on a factor $\mathrm{t}$ (Student $\mathrm{t}$ distribution) determined by the number of negative controls and the desired confidence level. This study used serum samples from 12 healthy buffaloes that were not cohabiting with other animals and did not have any history of tick infestation. The samples were provided by the Brazilian Agricultural Research Corporation (Embrapa), from its Temperate Zone Division, in Pelotas, Rio Grande do Sul, Brazil. The desired confidence level was $99 \%$.

For all the plates, spectrophotometric readings were taken until the positive control reached an OD of 1.0. For the positive control of the assay, bovine serum that was positive for B. burgdorferi was used. This was produced at the Parasitic Diseases Laboratory of the Animal Health project, under an agreement between UFRRJ and Embrapa. The production consisted of experimental inoculation of a healthy 50-day-old calf of $36 \mathrm{~kg}$ live weight, originating from the animal reproduction sector, Institute of Zootechnics, UFRRJ, using the methodology described by Ishikawa et al. (1997).

The statistical analyses were done using Fisher's exact test and the chi-square test, at the $5 \%$ confidence level.

\section{Results}

The antigen concentration of $20 \mu \mathrm{g} / \mathrm{mL}$ and the serum dilution of 1:400 and conjugate dilution of 1:5000 were the ones that gave the greatest difference (factor of 3.2 times) between the positive and negative serum samples. Therefore, these concentrations were used to modify the technique of Ishikawa et al. (1997).

The ELISA assay on 491 buffalo serum samples showed that 412 animals $(83.9 \%)$ presented homologous antibodies of IgG class directed towards $B$. burgdorferi antigens. The animals in the Arari microregion of Marajó Island showed positivity of $81.7 \%$ $(232 / 284)$, which did not differ statistically $(p=0.1488)$ from the positivity of $86.7 \%(180 / 207)$ observed in the microregions of Castanhal and Bragantina, located on the continental part of the state of Pará.

The frequencies of $B$. burgdorferi antibodies for each municipality are shown in Table 1. It was observed that the municipality of Santa Isabel showed the lowest frequency of positivity, but that this did not differ statistically from the municipality of Cachoeiras

Table 1. Frequency of homologous anti-Borrelia burgdorferi IgG antibodies in serum samples from buffaloes in the state of Pará, Brazil, as determined by means of the indirect ELISA test.

\begin{tabular}{lcc}
\hline \multicolumn{1}{c}{ Municipality } & $\begin{array}{c}\text { Total number of } \\
\text { samples }\end{array}$ & Frequency (\%) \\
\hline Cachoeiras do Arari & 284 & $232(81.7)^{\mathbf{a} b}$ \\
Castanhal & 66 & $57(86.4)^{\mathbf{a}}$ \\
Santa Isabel & 22 & $14(63.6)^{\mathbf{b}}$ \\
Nova Timboteua & 56 & $52(92.9)^{\mathbf{c}}$ \\
Santarém Novo & 63 & $57(90.5)^{\mathbf{a c}}$ \\
Total & 491 & $412(83.9)$ \\
\hline
\end{tabular}

Values with the same letters do not differ from each other according to Fisher's exact test, at the $5 \%$ significance level. 
do Arari $(\mathrm{p}=0.0510)$. The percentages of positive findings in the other municipalities were statistically similar. The only exception was seen in Nova Timboteua, which presented a higher frequency than in Cachoeiras do Arari $(\mathrm{p}=0.0472)$.

\section{Discussion and Conclusions}

In carrying out serological tests for $B$. burgdorferi among ruminants, especially when using crude antigen, the possibility of cross-reactions with Borrelia theileri should not be ruled out (ROGERS et al., 1999), especially since this agent is a spirochete that commonly affects cattle and horses, for which the main vector is the tick Rhipicephalus (Boophilus) microplus (SMITH; ROGERS, 1998). According to Barbour and Hayes (1986), the cross-reaction between these species can probably be partly explained by the fact that these spirochetes share a common flagellar antigen of $41 \mathrm{kDa}$, which is genus-specific to Borrelia. Ji et al. (1994) also reported the existence of cross-reactivity due to the $41 \mathrm{kDa}$ antigen of B. burgdorferi, in an ELISA test done on cattle infected by $B$. theileri.

The lack of existence of a commercial buffalo anti-IgG conjugate and the close phylogenetic relationship between cattle and buffaloes, with strong homology between the immunoglobulins of the two species (CALLOW et al., 1976), justified the use of anti-cattle conjugate in the present study.

Use of highly specific recombinant proteins, such as those with molecular weights of $31 \mathrm{kDa}(\mathrm{OspA}), 34 \mathrm{kDa}(\mathrm{OspB}), 35 \mathrm{kDa}$ (vlsE) and $110 \mathrm{kDa}$ in the ELISA test, has improved the specificity of detection of antibodies against $B$. burgdorferi in humans, dogs, horses and cattle (GREENE et al., 1988; CAPUTA et al., 1991; MAGNARELLI et al., 1997, 2004, 2010). However, few data are available in relation to the performance and suitability of ELISA tests done with recombinant antigens. It is known that B. burgdorferi changes the expression of its surface antigens to avoid the host immune response (LIANG et al., 2004). In this respect, use of the whole antigen of $B$. burgdorferi gives higher sensitivity to the ELISA test (MAGNARELLI et al., 2004), and this is a suitable antigen for initial investigation and screening of a large number of serum samples.

Serological research among animals has shown that there is no significant relationship between the antibodies against $B$. burgdorferi, Leptospira sp. and Treponema sp. that causes a cross-reaction (MAGNARELLI et al., 1987; SOARES et al., 1999). High specificity (97\%) has also been encountered among antibodies against B. burgdorferi, Leptospira interrogans, Brucella sp., Anaplasma marginale and Anaplasma phagocytophilum (MAGNARELLI et al., 2004).

In Brazil, seroepidemiological studies on domestic animals have already detected antibodies against $B$. burgdorferi in dogs (SOARES et al., 1999), horses (MADUREIRA et al., 2007; GALLO et al., 2009) and cattle (GUEDES JUNIOR et al., 2008). The frequency of seropositive buffaloes in the present work $(83.9 \%)$ was markedly greater than the rate of $54.9 \%$ observed among cattle (GUEDES JUNIOR et al., 2008) and the $26.7 \%$ found among horses (GALO et al., 2009), in the same region. These differences in frequencies of seropositive animals may be connected with greater susceptibility among buffaloes and with the intrinsic immunological factors of each animal species. This draws attention to the possible importance of buffaloes in the epidemiology of borreliosis.

The high frequency of seropositive animals encountered, the presence of the vector $R$. (Boophilus) microplus and the possible presence of buffaloes infected with Borrelia spp. in the region, suggests that there is a cross-reaction between the G39/40 strain of $B$. burgdorferi, which is used as an antigen in the ELISA test, and the species or strain of Borrelia that possibly infects buffaloes in the state of Pará.

It is known that cattle are susceptible to infection by $B$. theileri, B. burgdorferi and Borrelia coriaceae. However, in Brazil, infection due to $B$. coriaceae still has not been detected, and there has also not been any successful isolation of $B$. burgdorferi. Recently, Mantovani (2010) suggested that $B$. burgdorferi lato sensu was a microorganism of atypical morphology for which culturing in aerobic and anaerobic media (including BSK) was impossible, and that it was observed in Brazilian patients with a disease similar to Lyme borreliosis. This affirmation was based on amplification and sequencing of a fragment of the gene $f g E$, which is responsible for synthesis of the flagellar hook of $B$. burgdorferi, and this author had also identified this spirochete in ticks on horses and cattle in the states of Espírito Santo and Rio de Janeiro, with 99\% homology. Amplification and sequencing of the entire gene $f g E$ and further studies need to be conducted with the aim of proving these indications.

This was the first seroepidemiological study on borreliosis in buffaloes in the northern region of Brazil, and it demonstrated that buffaloes in the region studied are highly seropositive for anti-Borrelia burgdorferi antigens.

\section{Acknowledgements}

The authors thank Dr. Flábio R. Araújo and National Research Center for Beef Cattle of the Brazilian Agricultural Research Corporation (Embrapa Gado de Corte) and CNPq and FAPERJ for financial support.

\section{References}

Barbour AG, Hayes SF. Biology of Borrelia species. Microbiol Rev 1986; 50(4): 381-400. PMid:3540570. PMCid:373079.

Callow LL, Parker RJ, Rodwell BJ, Ottley ML. Piroplasmosis in buffaloes and its serological diagnosis based on a homology between buffalo and bovine immunoglobulins. Aust Vet J 1976; 52(1): 40-41. http://dx.doi. org/10.1111/j.1751-0813.1976.tb05367.x

Caputa AC, Murtaugh MP, Bey RF, Loken KI. 110-Kilodalton recombinant protein which is immunoreactive with sera from humans, dogs, and horses with Lyme borreliosis. J Clin Microbiol 1991; 29(11): 2418-2423. PMid:1774245. PMCid:270349.

Frey A, Canzio JD, Zurakowski D. A statistically defined endpoint titer determination method for immunoassays. I Immunol Methods 1998; 221(1-2): 35-41. http://dx.doi.org/10.1016/S00221759(98)00170-7

Galo KR, Fonseca AH, Madureira RC, Barbosa Neto JD. Freqüência de anticorpos homólogos anti-Borrelia burgdorferi em eqüinos na mesorregião metropolitana de Belém, Estado do Pará. Pesq Vet Bras 2009; 29(3): 229-232. 
Greene RT, Walker RL, Nicholson WL, Heidner HW, Levine JF, Burgess $\mathrm{EC}$, et al. Immunoblot analysis of immunoglobulin $\mathrm{G}$ response to the Lyme disease agent (Borrelia burgdorferi) in experimentally and naturally exposed dogs. J Clin Microbiol 1988; 26(4): 648-653. PMid:3366860. PMCid:266399.

Guedes Junior DS, Araújo FR, Silva FJM, Rangel CP, Barbosa Neto JD, Fonseca AH. Frequency of antibodies to Babesia bigemina, B. bovis, Anaplasma marginale, Trypanosoma vivax and Borrelia burgdorferi in cattle from the northeastern region of the state of Pará, Brazil. Rev Bras Parasitol Vet 2008; 17(2): 105-109. PMid:18823579.

Ishikawa MM, Fonseca AH, Soares CO, Massard CL, Yoshinari NH. Padronização de ensaio imunoenzimático ELISA indireto para pesquisa de anticorpos IgG contra Borrelia burgdorferi em bovinos. Rev Bras Med Vet 1997; 19(4): 166-168.

Ji B, Thomas CB, Collins MT. Evaluation of an enzyme-linked immunosorbent assay that uses the $41-\mathrm{kd}$ flagellin as the antigen for detection of antibodies to Borrelia burgdorferi in cattle. Am J Vet Res 1994; 55(9): 1213-1219. PMid:7802386.

Láu HD. Doenças em búfalos no Brasil: Diagnóstico, epidemiologia e controle. Brasília: Embrapa-SPI; Belém: Embrapa-CPATU; 1999. 202 p.

Liang FT, Yan J, Mbow ML, Sviat SL, Gilmore RD, Mamula M, et al. Borrelia burgdorferi Changes Its Surface Antigenic Expression in Response to Host Immune Responses. Infect Immun 2004; 72(10): 5759-5767. http://dx.doi.org/10.1128/IAI.72.10.5759-5767.2004

Little SE, Heise SR, Blagburn BL, Callister SM, Mead PS. Lyme borreliosis in dogs and humans in the USA. Trends Parasitol 2010; 26(4): 213-218. http://dx.doi.org/10.1016/j.pt.2010.01.006

Madureira RC, Corrêa FN, Cunha NC, Guedes Junior DS, Fonseca $\mathrm{AH}$. Ocorrência de anticorpos homólogos anti-Borrelia burgdorferi em eqüinos de propriedades dos municípios de Três Rios e Vassouras, estado do Rio de Janeiro. Rev Bras Ci Vet 2007; 14(1): 43-46.

Magnarelli LA, Anderson JF, Johnson RC. Cross-reactivity in Serological Tests for Lyme Disease and Other Spirochetal Infections. J Infect Dis 1987; 156(1): 183-188. http://dx.doi.org/10.1093/infdis/156.1.183
Magnarelli LA, Flavell RA, Padula SJ, Anderson JF, Firkrig E. Serologic diagnosis of canine and equine borrelioses: use of recombinant antigens in enzyme-linked immunosorbent assays. J Clin Microbiol 1997; 35(1): 169-173. PMid:8968901. PMCid:229532.

Magnarelli LA, Bushmich SL, Sherman BA, Fikrig E. A comparison of serologic tests for the detection of serum antibodies to wholecell and recombinant Borrelia burgdorferi antigens in cattle. Can Vet J 2004; 45(8): 667-674. PMid:15368740. PMCid:546445.

Magnarelli LA, Williams SC, Fikrig E. Seasonal prevalence of serum antibodies to whole cell and recombinant antigens of Borrelia burgdorferi and Anaplasma phagocytophilum in white-tailed deer in Connecticut. J Wildl Dis 2010; 46(3): 781-790. PMid:20688684.

Mantovani E. Identificaçâo do agente etiológico da Doença de Lyme-símile brasileira (Sindrome Baggio-Yoshinari) [Tese]. São Paulo: Faculdade de Medicina, Universidade de São Paulo; 2010. 117 p.

Nithikathkul C, Polseela P, Changsap B, Leemingsawat S. Ixodid ticks on domestic animals in Samut Prakan Province, Thailand. Southeast Asian J Trop Med Public Health 2002; 33(S3): 41-44. PMid:12971472.

Rogers AB, Smith RD, Kakoma I. Serologic cross-reactivity of antibodies against Borrelia theileri, Borrelia burgdorferi and Borrelia coriaceae in cattle. Am J Vet Res 1999; 60(6): 694-697. PMid:10376894.

Rudenko N, Golovchenko M, Lin T, Gao L, Grubhoffer L, Oliver Junior JH. Delineation of a New Species of the Borrelia burgdorferi sensu lato Complex, Borrelia americana sp. nov. J Clin Microbiol 2009; 47(12): 3875-3880. http://dx.doi.org/10.1128/ JCM.01050-09

Smith RD, Rogers AB. Borrelia theileri: A review. J Spirochetal Tick-borne Dis 1998; 5(4): 63-68.

Soares CO, Fonseca AH, Ishikawa MM, Manera GB, Scofield A, Yoshinari NH. Sorologia para borreliose em cães procedentes da Baixada Fluminense, estado do Rio de Janeiro. Rev Bras Med Vet 1999; 21(3): 111-114. 